\title{
GONDANG DAN SISTEM KEKERABATAN ETNIK ANGKOLA
}

\author{
LIDIA EPANGELIA \\ Program Studi Pendidikan Musik
}

\begin{abstract}
This study aims to find out the Angkola ethnic kinship system, to know Angkola gondang shape and to interpret the relationship of gondang and the ethnic kinship system of Angkola. This research is based on a theoretical explaining the understanding of gondang and the Angkola ethnic kinship system by using the theory of deconstruction, semiotics and ethnomusicology. This research was conducted from September 2017 to October 2017 in Kecamatan Arse, Simangambat Street, KM. 11, Arse Nauli. The research method used is descriptive qualitative. The population in the study was non-existent and the research sample consisted of five indigenous figures and Angkola artists. The research result explores that gondang and relatives of ethnic Angkola are needed in showing their identity as ancestral cultural heritage which deserves to be appreciated by society. The relationship between gondang and the ethnic kinship system of Angkola states that gondang is a representation of the kinship system by looking at the relationship between each instrument in Angkola gondang ensemble which is a manifestation of na tolu transition in traditional ceremony.
\end{abstract}

Keywords: Gondang, Kinship System, Ethnic Angkola 


\section{PENDAHULUAN}

\section{A. Latar Belakang}

Sungguh satu negeri nan makmur bila memiliki keberagaman budaya dengan pesona alam yang indah sebuah Mahakarya Sang Pencipta. Namun dalam keberagaman budaya yang diemban tidak selalu stabil oleh pertemuannya dengan budaya lain. Lestarinya suatu keutuhan atas kebertahanan budaya merupakan tindak aktif manusia sebagai masyarakat yang mengelolanya. Keberagaman budaya Angkola adalah salah satu dari sub etnik Batak yang terletak di daerah Tapanuli Selatan, yang terdiri dari tiga daerah yakni Angkola Jae, Angkola Julu, dan Angkola Dolok. Adapun daerah yang penulis kunjungi adalah daerah Angkola Jae yang berada di Kecamatan Arse. Angkola Jae, Kecamatan Arse berada $\pm 339,2$ KM dari Kota Medan.

Masyarakat Angkola sering melakukan acara adat yang melibatkan mora (pihak yang memberi istri kepada lelaki), kahanggi (pihak keluarga semarga), dan anak boru (pihak yang mengambil istri bagi lelaki). Ketiga tersebut dimiliki oleh Indonesia dan salah satu komunitas etniknya adalah etnik Angkola yang memiliki sistem pranata hidup berlandaskan aturan norma serta nilai yang dibentuk para leluhur dalam sistem kekerabatan yang adalah representasi gondang Angkola. Pertemuan budaya-budaya yang tidak selalu berproses seimbang menghadapkan masyarakat Angkola untuk menyatakan kesetiaannya dalam menjaga warisan budaya leluhur.

pihak ini merupakan satu sistem kekerabatan yang selalu bekerja sama untuk terselenggaranya acara adat. Aturan adat istiadat yang menyatukan nilai persaudaraan pada komunitas etnik Angkola beresensikan nilai filosofis dari warisan leluhurnya, sehingga nilai persaudaraan tersebut terkandung secara eksplisit di dalam sistem kekerabatan.

Kesenian tradisional masyarakat Angkola dapat memberikan pendidikan adat istiadat, etika, dan rasa solidaritas yang dibangun berdasarkan adanya niat kebersamaan dalam masyarakat 
Angkola. Nilai-nilai khas yang mencerminkan kepribadian masyarakat Angkola berkaitan dengan sistem kekerabatan masyarakat yang disebut Dalihan $\mathrm{Na}$ Tolu, yaitu, terdiri dari mora, kahanggi, dan anak boru. Dalam suatu acara adat istiadat sistem kekerabatan mengambil peranan penting dan gondang turut berperan serta mengisi keharmonisasian suatu acara. Ketika mora, kahanggi, dan anak boru berbicara dalam peradatan demikian halnya gondang Konkretnya eksplanasi dari latar belakang akan dibahas pada bab selanjutnya. Dalam kesempatan ini penulis menyatakan judul penelitian "Gondang dan Sistem Kekerabatan Etnik Angkola."

\section{B. Tujuan Penelian}

1. Untuk memahami Sistem Kekerabatan Etnik Angkola.

2. Untuk mengetahui wujud gondang etnik Angkola.

3. Untuk menginterpretasi hubungan Gondang dan Sistem Kekerabatan Etnik Angkola.

\section{LANDASAN TEORITIS}

mengiringi kedaulatan wibawa setiap posisi mora, kahanggi, dan anak boru melalui bunyi-bunyi yang menyatakan suatu kesakralan hubungan di dalam acara adat istiadat tersebut. Makna yang terkandung dalam unsur-unsur bunyi pada gondang Angkola dipresentasikan dari sistem kekerabatan dalam Dalihan Na Tolu. Sistem kekerabatan yang menjadi representasi gondang Angkola membuat hubungan di antara keduanya menghasilkan makna.

Dalam penelitian kualitatif yang bersifat holistik, jumlah teori yang harus dimiliki oleh peneliti kualitatif jauh lebih banyak karena harus disesuaikan dengan fenomena yang berkembang di lapangan (Sugiyono, 2016: 213).

\section{A. Pengertian Gondang}

Kata gondang berarti instrumen, yaitu gendang (membranophone) yang terdiri dari gondang inang atau gondang siayakon dan gondang pangayakon. Kedua, gondang bisa berarti lagu, misalnya lagu untuk suhut sihabolonan maka disebut dengan 
gondang mora. Ketiga, gondang dapat juga berarti ansambel musik yakni instrumen-instrumen yang tergabung dalam satu unit.

\section{B. Pengertian}

Sistem

\section{Kekerabatan}

Sistem kekerabatan adalah

pola, aturan, bentuk, yang mempunyai komponen

(components), batas (boundary), lingkungan (environments), penghubung (interface), masukan (input), pengolahan (processing), jenis (misalnya, anak-anak dari saudara laki-laki atau perempuan).

\section{Etnik Angkola}

Etnik Angkola adalah suatu kelompok sosial yang mempunyai tradisi kebudayaan dan sejarah. Adanya ciri khas dapat menjadi suatu identitas subkelompok dalam masyarakat yang luas (bangsa). Kelompok etnik bisa memiliki bahasa sendiri, agama, tradisi, dan adat istiadat yang berbeda dengan kelompok yang lain. Etnik Angkola dibagi dalam tiga wilayah hukum adat, yaitu: wilayah hukum adat keluaran (output), sasaran (objectives) dan tujuan (goal), kendali (control), dan umpan balik dalam suatu hubungan yang dibangun berdasarkan keluarga inti, sanak famili, teman sejawat/kerja, dalam meningkatkan skala menjadi sistem sosial yang mencapai kompleksitas yang lebih tinggi. Masyarakat ditandai oleh aturanaturan bahwa seseorang harus menikah dengan sepupu-silangnya. Sepupu silang adalah anak-anak dari saudara sekandung yang berlawanan Angkola Jae, Julu dan Angkola Dolok atau daerah Sipirok.

\section{Teori Dekonstruksi}

Bergesernya zaman, seolah menggeser kebertahanan jati diri budaya masyarakat Angkola. Globalisasi memperhadapkan budaya Angkola untuk menunjukkan kebertahanan jati diri budaya dalam adat istiadat. Pengaruh budaya luar seakan-akan menghentikan langkah pewarisan budaya leluhur. Masyarakat Angkola kini kurang memperhatikan keberadaan gondang sebagai warisan leluhur, sehingga penggunaanya pun mulai jarang 
ditemukan baik lokal ataupun nasional, karena masyarakat mulai beralih dengan penggunaan musik modern, yang berasal dari budaya modern dalam arus globalisasi. Makna eksplisit dan implisit dari gondang mulai kurang diperhatikan. Musik dengan penggunaan gondang dianggap tidak sesuai dengan perkembangan zaman. Melalui eksplanasi tersebut, maka teori dekonstruksi digunakan oleh penulis untuk membongkar makna dan membuat konstruksi baru dengan menemukan hubungan Gondang dan Sistem Kekerabatan Etnik Angkola.

\section{E. Teori Semiotika}

Ketika berbicara mengenai semiotika, maka tidak terlepas dari tanda. Semiotika berusaha menjelaskan jalinan tanda atau ilmu tentang tanda; secara sistematik menjelaskan esensi, ciri-ciri, dan bentuk suatu tanda, serta proses signifikasi yang menyertainya. Banyak tanda-tanda yang terdapat pada Gondang dan Sistem Kekerabatan Etnik Angkola, baik dari posisi duduk bermain gondang, jenis ritme dan melodi ansambel gondang, posisi bernyanyi si penyanyi (paronang-onang), bentuk ukiran-ukiran pada gondang, posisi badan si penari (panortor), barangbarang kebesaran adat, kewajiban goruk-goruk hapinis mempersembahkan sekapur sirih kepada para tamu dalam paradaton, dan masih banyak lagi. Tanda ini akan dimaknai oleh teori tanda Semiotika.

\section{F. Teori Etnomusikologi}

Salah satu fungsi etnomusikologi menurut Alan.P.Merriam adalah sebagai komunikasi antar komunitas masyarakat. Berdasarkan keterangan tersebut bahwa, gondang bukan berfungsi hanya sebagai hiburan, fungsi kesakralan yang terdapat dalam adat istiadat mengandung nilai-nilai sebagai pertahanan jati diri budaya Angkola. Keragaman asalusul kita merupakan suatu kelebihan dan bukan kekurangan. Dalam beberapa hal, keberadaan etnomusikologi dapat ditarik dari penggunaan materi musik rakyat. Bunyi yang disampaikan oleh gondang dari sistem kekerabatan, 
mengandung makna budaya Angkola yang diwariskan oleh para leluhur dalam adat istiadat. Maka dari itu, penulis menggunakan teori etnomusikologi sebagai pembedah estetika makna gondang dalam bunyi-bunyi yang disampaikannya, sehingga gondang dapat dipahami esensinya sebagai bentuk kesenian tradisional etnik Angkola.

\section{METODOLOGI PENELITIAN}

\section{A. Metode Penelitian}

Metode penelitian kualitatif sering disebut metode penelitian naturalistik kerena penelitiannya dilakukan pada kondisi yang alamiah (natural setting); disebut juga sebagai metode etnographi, karena pada awalnya metode ini lebih banyak digunakan untuk penelitian bidang antropologi budaya; disebut sebagai metode kualitatif, karena data yang terkumpul dan analisisnya lebih bersifat kualitatif (Sugiyono, 2016: 8).

\section{B. Tempat dan Waktu Penelitian}

Berdasarkan judul penelitian Gondang dan Sistem Kekerabatan
Etnik Angkola, penelitian akan dilaksanakan di Jalan Simangambat, KM.11, Kecamatan Arse, Kota Sipirok, Kabupaten Tapanuli Selatan, Provinsi Sumatera Utara. Sedangkan waktu penelitian dimulai bulan September-November 2017.

\section{Populasi dan Sampel}

1. Populasi

Dalam penelitian kualitatif tidak menggunakan istilah populasi, tetapi oleh Spardley dinamakan "social situation" atau situasi sosial yang terdiri atas tiga elemen yaitu: tempat (place), pelaku (actors), dan aktivitas (activity) yang berinteraksi secara sinergis. Situai sosial tersebut, dapat di rumah berikut keluarga dan aktivitasnya, atau orang-orang di sudut-sudut jalan yang sedang ngobrol, atau di tempat kerja, di kota, desa atau wilayah suatu negara. Situasi sosial tersebut, dapat dinyatakan sebagai obyek penelitian yang ingin diketahui "apa yang terjadi” di dalamnya. Pada situasi sosial atau obyek penelitian ini peneliti dapat mengamati secara mendalam aktivitas (activity) orangorang (actors) yang ada pada tempat 
(place) tertentu (Sugiyono, 2016: 215).

\section{Sampel}

Sampel dalam penelitian ini adalah seorang tokoh adat Angkola, seorang penyanyi, seorang pemain gondang, dan seorang warga yang selalu setia menyaksikan acara adat istiadat yang diisi oleh gondang Angkola.

\section{PEMBAHASAN}

\section{A. Sistem Kekerabatan}

Etnik Angkola mengenal sistem kekerabatan yang disebut Dalihan $\mathrm{Na}$ Tolu. Pengertian Dalihan Na Tolu ialah tungku nan tiga. Dalihan $\mathrm{Na}$ Tolu merupakan suatu lembaga adat yang penting dalam masyarakat, terdiri atas tiga kelompok yaitu Mora (pihak yang memberi istri kepada lelaki), Kahanggi (pihak keluarga semarga) dan Anakboru (pihak yang mengambil istri bagi lelaki). Dalihan Na Tolu dapat disebut juga sebagai dewan musyawarah yang disebut Partahian yaitu yang menentukan segala sesuatu dalam melaksanakan upacara adat.
Istilah pertuturan hubungan kekerabatan antara masyarakat satu dengan lainnya dikembangkan sesuai pertuturan Dalihan Na Tolu. Maka dari itu istilah pertuturan tersebut dapat diuraikan dari Mora, Kahanggi dan Anak boru.

Adapun yang menjadi pembahasan penulis yaitu mengenai horja siriyaon dalam horja boru (pesta penikahan).

Pengertian horja boru bukanlah pihak boru yang bekerja melainkan istilah tersebut memiliki arti pesta pernikahan. Horja boru terdiri atas tiga bagian, yaitu horja saborngin (pesta sehari), horja tolu ari tolu borngin (pesta tiga hari tiga malam), dan horja pitu ari pitu borngin (pesta tujuh hari tujuh malam). Pelaksanaan kegiatan dalam upacara horja boru teridiri atas panaekhon horja (nama acara) dan mata ni horja (puncak acara). Bagian dari panaekhon horja adalah manaekkon gondang, manortor, manjagit haroro ni boru, mangaloalo mora, marosong-osong, maralokalok. Bagian mata ni horja adalah manyingkohi, patuaekhon, mangupa, mamondul. 


\section{B. Gondang Angkola}

Gondang pada penelitian ini adalah gondang Angkola. Gondang Angkola merupakan instrumen berjenis membranophone yaitu jenis alat musik pukul. Melakukan aktivitas musik bagi kebudayaan Angkola ada yang disebut bermain gondang/margondang. Gondang adalah salah satu jenis alat musik yang terdapat di daerah Angkola yang dipakai dalam pelaksanaan upacara adat. Kata gondang sendiri dapat berarti nama instrumen yaitu gondang pangayak dan siayakon. Selain nama sebuah instrumen, gondang juga dapat dikatakan sebagai ansambel, yaitu kumpulan beberapa alat musik dari beberapa klasifikasi musik seperti, sebuah ansambel musik gondang Angkola terdiri atas, dua buah gondang, satu set gong, sebuah doal, sebuah suling dan sebuah tali sayak. Tiruan bunyi yang dihasilkan oleh gondang Angkola adalah menggunakan kata "Dum, Cap dan I".

C. Hubungan Gondang Dan Sistem Kekerabatan Etnik Angkola
Berdasarkan eksplanasiekplanasi gondang dan sistem kekerabatan etnik Angkola yang telah diuraikan dapat disimpulkan bahwa gondang merupakan representasi dari keberadan sistem kekerabatan etnik Angkola. Gondang adalah simbol ataupun wujud dari dalihan na tolu dalam upacara adat horja siriyaon. Demikian teori semiotika membantu untuk membuka wawasan keberadaan gondang sebagai simbol, tanda ekstrinsik yang dapat di jangkau oleh panca indera yang imanen bahkan yang transenden. Melalui teori dekonstruksi, penulis menemukan bahwa kesadaran akan kebertahanan warisan budaya leluhur perlu untuk mendapatkan pembongkaran ide untuk menemukan makna ekstrinsik maupun intrinsik. Etnomusikologi bekerja melalui bunyi-bunyi musik tradisi adalah wujud identitas etnik tersebut. Rangkaian bunyi yang melambangkan jati diri suatu etnik dapat diketahui dengan mendengar bunyi itu sendiri. Dalam hal ini, bunyi ansambel gondang Angkola adalah wujud identitas diri etnik Angkola yang mencerminkan nilai- 
nilai, norma-norma, rasa solidaritas yang melekat pada budaya masyarakat Angkola.

\section{KESIMPULAN DAN SARAN}

\section{Kesimpulan}

1.1 Sistem kekerabatan etnik Angkola dapat dilihat pada wujud horja boru seperti manyantan gondang, manortor, marosong-osong, mangalo-alo mora, maralok-alok, patuaekkon, mangupa merupakan simbol upacara adat istiadat yang menunjukkan sikap untuk saling menghargai baik individu, sesama maupun Sang Pencipta.

1.2 Wujud gondang Angkola yang disebut sebagai ansambel terdiri atas, sebuah suling, gondang paroban dan gondang pangayak, sepasang gong, sebuah doal dan sebuah tali sayak.

1.3 Hubungan gondang dan sistem kekerabatan etnik Angkola didapatkan dengan keberadaan gondang yang utuh dalam upacara adat merupakan perwakilan dari sistem kekerabatan dan bersifat representatif. Wujud suling merupakan suhut sihabolonan, wujud gondang paroban merupakan harajaon, hatobangon dan raja panusunan bulung, wujud gondang pangayak merupakan na pande atau orang kaya, wujud doal dan tali sayak merupakan anak boru dan pisang raut dan wujud gong merupakan mora.

\section{DAFTAR PUSTAKA}

Barker, Chris, 2004. Cultural Studies $\begin{array}{llr}\text { Teori \& } & & \text { Praktik. } \\ \text { Yogyakarta } \\ \text { Wacana. }\end{array}$

Batubara, 2016. Kajian Organologi Gendang Melayu Pakpung di Kota Stabat Kabupaten Langkat. Yogyakarta : LKiS Yogyakarta.

Danesi, Marcel, 2010. Pesan, Tanda, dan Makna: Buku Teks Dasar Mengenai Semiotika dan Teori Komunikasi. Yogyakarta : Jalasutra.

Diapari, 1980. Perkembangan Adat Istiadat Masyarakat Suku Batak Tapanuli Selatan Suatu Tinjauan.

Ginting, Pulumun, 2015. Spiritualitas Upacara Gendang Kematian Etnik Karo pada Era Globalisasi. Denpasar : Disertasi. 
Harahap, Deliana et al, 2004. Pluralitas Musik Etnik: Batak-Toba, Mandailing, Melayu, Pakpak-Dairi, Angkola, Karo, dan Simalungun. Medan : Pusat Dokumentasi dan Pengkajian Kebudayaan Batak Universitas HKBP Nomensen.

Liliweri, 2005. Prasangka \& Konflik: Komunikasi Lintas Budaya Masyarakat Multikultur. Yogyakarta : LKiS Yogyakarta.

Merriam, Alan, 1984. The Antropologi. Chicago : The Museum of Natural History.

Moleong, 2017. Metodologi Penelitian Kualitatif. Bandung : PT. Remaja Rosdakarya.

Nettl, Bruno, 2012. Teori dan Metode dalam Etnomusikologi. Jayapura : Jayapura Center of Music.

Pasaribu, Ben et al, 2004. Pluralitas Musik Etnik: Batak-Toba, Mandailing, Melayu, Pakpak-Dairi, Angkola, Karo, dan Simalungun. Medan : Pusat Dokumentasi dan Pengkajian Kebudayaan Batak Universitas HKBP Nomensen.

Purba, Mauly et al, 2004. Pluralitas Musik Etnik: Batak-Toba, Mandailing, Melayu, Pakpak-Dairi, Angkola,
Karo, dan Simalungun. Medan : Pusat Dokumentasi dan Pengkajian Kebudayaan Batak Universitas HKBP Nomensen.

Ratna, Kutha, 2010. Metodologi Penelitian Kajian Budaya dan Ilmu-Ilmu Sosial Humaniora pada Umumnya. Yogyakarta : Pustaka Belajar.

Rohman, Saifur, 2014. Dekonstruksi: Desain Penafsiran dan Analisis. Yogyakarta : Penerbit Ombak (Anggota IKAPI).

Saifuddin, Achmad, 2006. Antropologi Kontemporer Suatu Pengatar Kritis Mengenai Paradigma. Jakarta : Kencana Prenada Media Group.

Setiadi, Elly et al, 2006. Ilmu Sosial dan Budaya Dasar. Jakarta : Kencana Prenada Media Group.

Simanjuntak, 2011. Pemikiran Tentang Batak: Setelah 150 Tahun Agama Kristen di Sumatera Utara. Jakarta : Yayasan Pustaka Obor Indonesia.

Sinaga, 2015. Gondang Hasapi pada Upacara Ritual Parmalim Si Pahasada di Huta Tinggi Kecamatan Laguboti Kabupaten Toba Samosir (Kajian Bentuk Penyajian dan Fungsi). Yogyakarta : LKiS Yogyakarta. 
Siregar, et al, 2002. Kamus AngkolaIndonesia. Medan : Yayasan Angkola Mandiri Sejahtera.

Sitepu, 2013. Peranan Ansambel Gendang Lima Sendalenan Dalam Tari Topeng Gundala-Gundala Seberaya di Desa Seberaya Kecamatan Tiga Panah Kabupaten Karo. Yogyakarta : LKiS Yogyakarta.

Sobur, Alex, 2006. Semiotika Komunikasi. Bandung : PT. Remaja Rosdakarya.

Sugiyono. 2016. Metode Penelitian Kuantitatif, Kualitatif, dan $R \& D$. Bandung : Alfabeta, cv.

Suhardi, et al, 1994. Arsitektur Tradisional Daerah Sulawesi Utara. Jakarta : Departemen Pendidikan dan Kebudayaan.
Sukmadinata, 2011. Metode Penelitian Pendidikan. Bandung : PT. Remaja Rosdakarya.

Supanggah, 1995. Etnomusikologi. Yogyakarta : Yayasan Bentang Budaya.

Suparlan, 1995. Orang-orang Sakai di Riau: Masyarakat Terasing dalam Masyarakat Indonesia. Jakarta Yayasan Obor Indonesia.

Sutanta, Edhy. 2003. Sistem Informasi Manajemen. Yo gyakarta : Graha Ilmu.

Tarigan, 2013. Kajian Organologi Gendang Singindungi dan Gendang Singanaki di Desa Pancur Batu Kabupaten Deli Serdang. Yogyakarta : LKiS Yogyakarta.

www.tobadetour.com

www.silaban.net 